Lynn M. Barry

Lynn M. Barry is an economist at the Federal Reserve Bank of St. Louis. Thomas A. Pollmann provided research assistance.

\title{
Eighth District Banks: Back in the Black
}

F and the Eighth Federal Reserve District, 1988

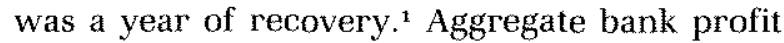
ratios in the United States and the Eighth District improved as many of the nation's larger banks began to recoup from losses associated with foreign loans. Further gains were made by smaller District banks, which posted higher earnings as loan loss provisions and loan chargeoffs declined. Asset quality also improved at small banks as nonperforming loans and actual loan losses decreased.

This article compares the performance of Eighth District commercial banks with their national counterparts across several asset-size categories. ${ }^{z}$ An analysis of bank earnings, asset quality and capital adequacy provides useful information on the financial condition, regulation compliance and operating soundness of the District's banking industry.

\section{WR RNAGS}

Eighth District banks reported year-end earnings of $\$ 1.1$ billion in 1988, an increase of
$\$ 191.6$ million from 1987. The U.S. banking industry earned $\$ 25.1$ billion in 1988 , up sharply from $\$ 3.2$ billion in 1987. Sixty-eight banks, 5.3 percent of all District banks, reported negative earnings in 1988, down from 86 in 1987. Nationally, 13.7 percent of commercial banks reported net losses for the year compared with 18.2 percent in 1987. Much of the improvement in both District and U.S. bank earnings can be traced to lower loan loss provisions, which had a positive effect on earnings.

\section{Return on Assets and Lquify}

In analyzing bank earnings, there are two standard measures of bank performance: the return on average assets ( $\mathrm{ROA})$ and the return on equity (ROE) ratios. " "The ROA ratio, calculated by dividing a bank's net income by its average annual assets, shows how well a bank's management is using the company's assets. The ROE ratio, obtained by dividing a bank's net income by its equity capital, indicates to shareholders how much the institution is earning on their investment. ${ }^{4}$
The Eighth Federal Reserve District consists of the following: Arkansas, entire state; lllinois, southern 44 counties; Indiana, southern 24 counties; Kentucky. western 64 counties; Mississippi, northern 39 counties; Missouri, eastern and southern 71 counties and the City of St, Louis; Tennessee, western 21 counties

2For more specific bank performance statistics on each Eighth District state, see the Federal Reserve Bank of St. Louis' June 1989 issue of Pieces of Eight.
${ }^{3} \mathrm{~A}$ major concern with $\mathrm{ROA}$, ROE and other performance measures is that they are calculated using the book values of assets, liabilities and equity not the current market value.

4Equily capital includes common and perpelual preferred stock, surplus, uncivided profits and capilal reserves. 


\section{Table 1}

\section{Return on Average Assets and Return on Equity}

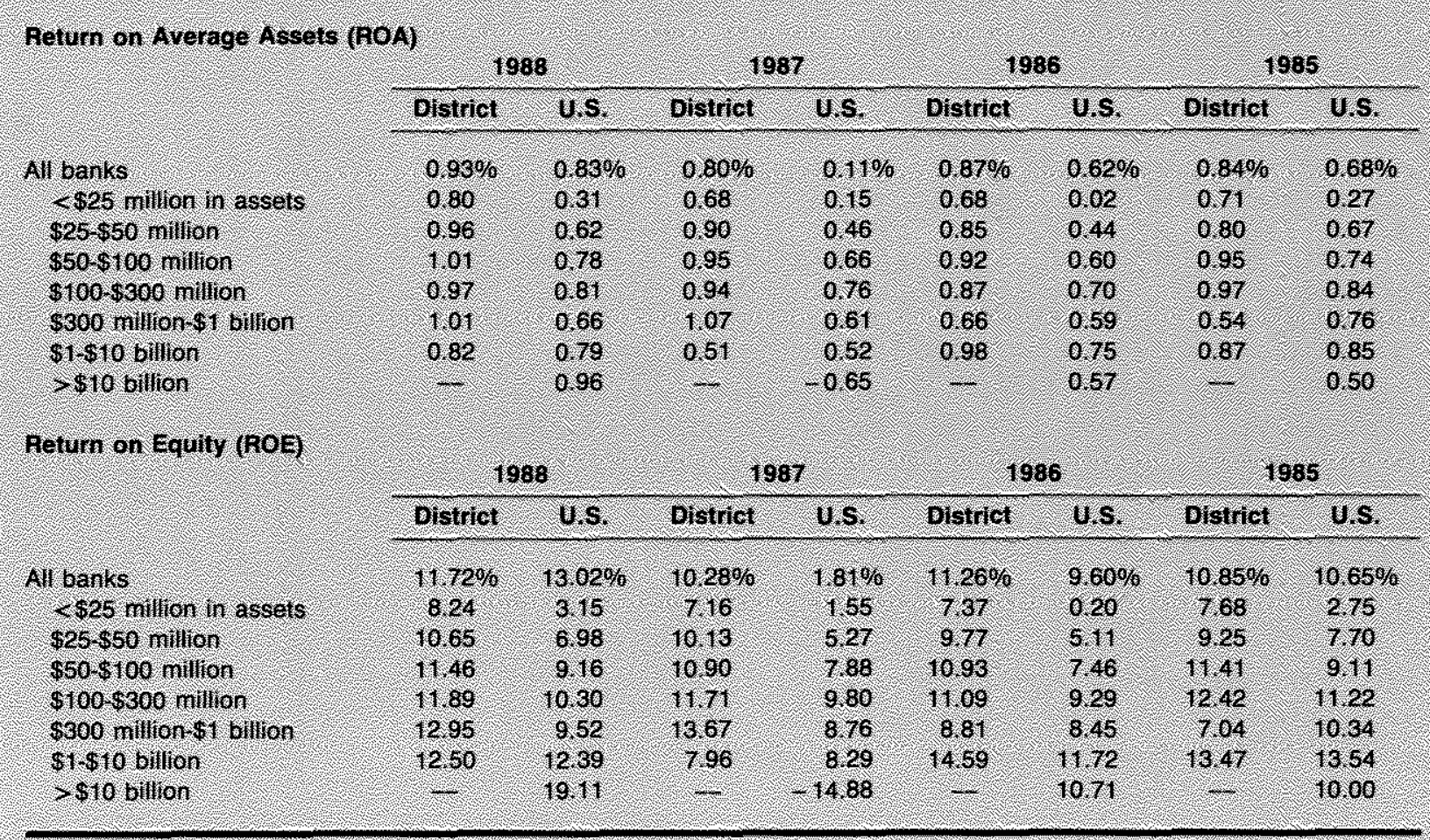

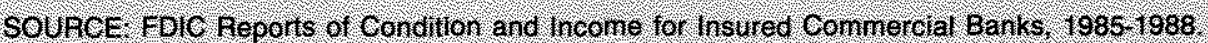

As table 1 reports, the 1988 average ROA and ROE for Eighth District banks was 0.93 percent. and 11.72 percent, respectively. Nationally, banks reported an average ROA of 0.83 percent and an average ROE of 13.02 percent. For each of the years presented, District ROA averages outperformed national averages. In 1988, ROAs for both the District and the nation improved significantly over 1987, when they were depressed by poor earnings associated with sus. pect foreign loans at the nation's largest banks.

Table 1 also shows ROAs and ROEs for seven asset-size categories of commercial banks. Across virtually every category, both Districtwide and nationwide, 1988 was a year of improvement. Of particular note are the strong earnings at banks with assets between $\$ 1$ billion and $\$ 10$ billion. District banks in this asset range reported average ROAs of 0.82 percent in 1988 , up from 0.51 percent in 1987 . Nationally, these banks reported a jump in ROA from 0.52 percent to 0.79 percent. ROA for banks with assets more than $\$ 10$ bilion (none of which are in the Eighth District) was the highest of the size groupings at 0.96 percent, a substantial improvement from -0.65 in 1987.

Another bright note in 1988 was the continued earnings improvement at smaller banks. For the periods reported in table 1, 1988 was the year in which District banks with assets less than $\$ 100$ million earned their highest ROAs and ROEs. Higher earnings for these banks were the direct result of lower loan loss provisions and a decline in loan charge-offs.

\section{Morghth Antulysis}

The financial success of a bank depends on its management's ability to generate sufficient revenue while controlling costs. Two important measures of management's success are net interest and net noninterest margins.

Net interest margin is the difference between what a bank earned on loans and investments and what it paid its depositors, divided by 


\section{Table 2}

\section{Net Interest Margin}

\begin{tabular}{|c|c|c|c|c|c|c|c|c|}
\hline & \multicolumn{2}{|c|}{1988} & \multicolumn{2}{|c|}{1987} & \multicolumn{2}{|c|}{1986} & \multicolumn{2}{|c|}{1965} \\
\hline & Distifict & U.s. & pistigl & $0 s$ & Disinict & u.s. & pistrat & Us. \\
\hline holvos & $4.26 \%$ & $427 \%$ & 4270 & 4,0900 & $4,40 \%$ & $4.180 \%$ & $431 \%$ & $427 \%$ \\
\hline < $\$ 25$ nimllon h assers & 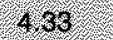 & 458 & 4.45 & 461 & (468) & 478 & 4.58 & $4.7 \%$ \\
\hline$\$ 25 \$ 50$ nillor & 4.29 & 4.56 & 465 & 459 & 2.56 & 475 & 421 & 460 \\
\hline$\$ 50-8100$ rinlion & 4.21 & 456 & 4.38 & 4.59 & 456 & 477 & 416 & 4,52 \\
\hline $5100 \mathrm{~s} 300 \mathrm{~m}$ m110\% & 426 & 459 & 439 & 459 & 4.4 & 468 & 454 & 486 \\
\hline 8300 vilillon s l bilion & 4.49 & 456 & 455 & 456 & 4,46 & 465 & 461 & 475 \\
\hline 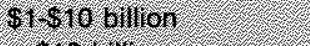 & 4.17 & 4045 & 6.97 & 4,36 & 414 & 425 & .707 & 441 \\
\hline$>1816 / 1110,0$ & 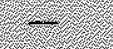 & 8.85 & es & 6.39 & rev & 360 & z & 8,49 \\
\hline
\end{tabular}

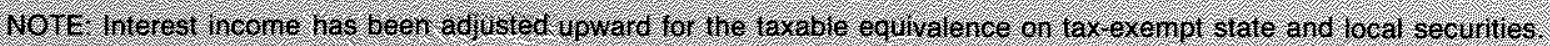

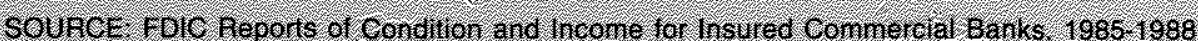

average earning assets. ${ }^{5}$ This ratio indicates how well interest-earning assets are being employed relative to interest-bearing liabilities. ${ }^{6}$

Higher net interest margins were one of the driving forces behind stronger earnings at the larger banks in both the District and the United States in 1988. As table 2 shows, District banks with assets between $\$ 1$ and $\$ 10$ billion reported an average net interest margin of 4.17 percent, a 20 basis-point increase from 1987. Nationally, these banks reported average net interest margins of 4.45 percent, up from 4.36 percent in 1987. The largest banks in the nation, those with assets more than $\$ 10$ billion, recorded an average net interest margin of 3.85 percent, up 46 basis points from 1987 averages. At banks with assets less than $\$ 1$ billion, net interest margins declined both Districtwide and nationwide in 1988. Banks across the nation, however, outperformed banks in the Eighth District for each of the asset-size categories reported in table 2 .

For District banks, interest income rose from 9.35 percent of average earning assets in 1987 to 9.63 percent in 1988. As figure 1 shows, interest income as a percent of earning assets was, on average, lower at District banks than at U.S. banks for each year except 1986. Nationally, interest income as a percent of earning assets rose from 9.62 percent in 1987 to 10.31 percent in 1988. In contrast, interest-related expenses, while rising from 5.08 percent of earning assets in 1987 to 5.37 percent in the District in 1988, were lower than the 1988 national average of 6.04 percent.

The net noninterest margin is an indicator of the efficiency of a bank's operations and its pricing and marketing decisions. The net noninterest margin is the difference between noninterest income (other) and noninterest expense (overhead) as a percent of average assets. Since noninterest expense generally exceeds noninterest income, the calculation yields a negative number; it is common practice, however, to report the net noninterest margin as a positive number. Thus, smaller net noninterest margins indicate better bank performance, holding all other things constant.

\footnotetext{
5Earning assets include: loans (net of unearned income) in domestic and foreign offices; lease financing receivables; obligations of U.S. government, states and political sub. divisions and other securities; assets held in trading accounis; interest-bearing balances due from depository institutions; federal funds sold and securities purchased under agreements to resell.

On the asset side, this includes both interest income and fees related to interest-earning assets. Examples include: interest on loans; points on loans; income on tax exempt
}

muricipal loans and bonds and income from holdings of U.S. government securities. On the liabitity side, interest expense includes: the amount paid on all categories of interest-bearing deposits; federal funds purchased and capital notes.

${ }^{7}$ Bank management should be concerned not only with the level of the net interest margin, but also with its variability over time. With volatile interest rates, the stability of the net interest margin indicates that the interest sensitivity of assets and liabilities is matched. 


\section{Figure 1 \\ Interest Income and Interest Expense as a Percent of Average Earning Assets}

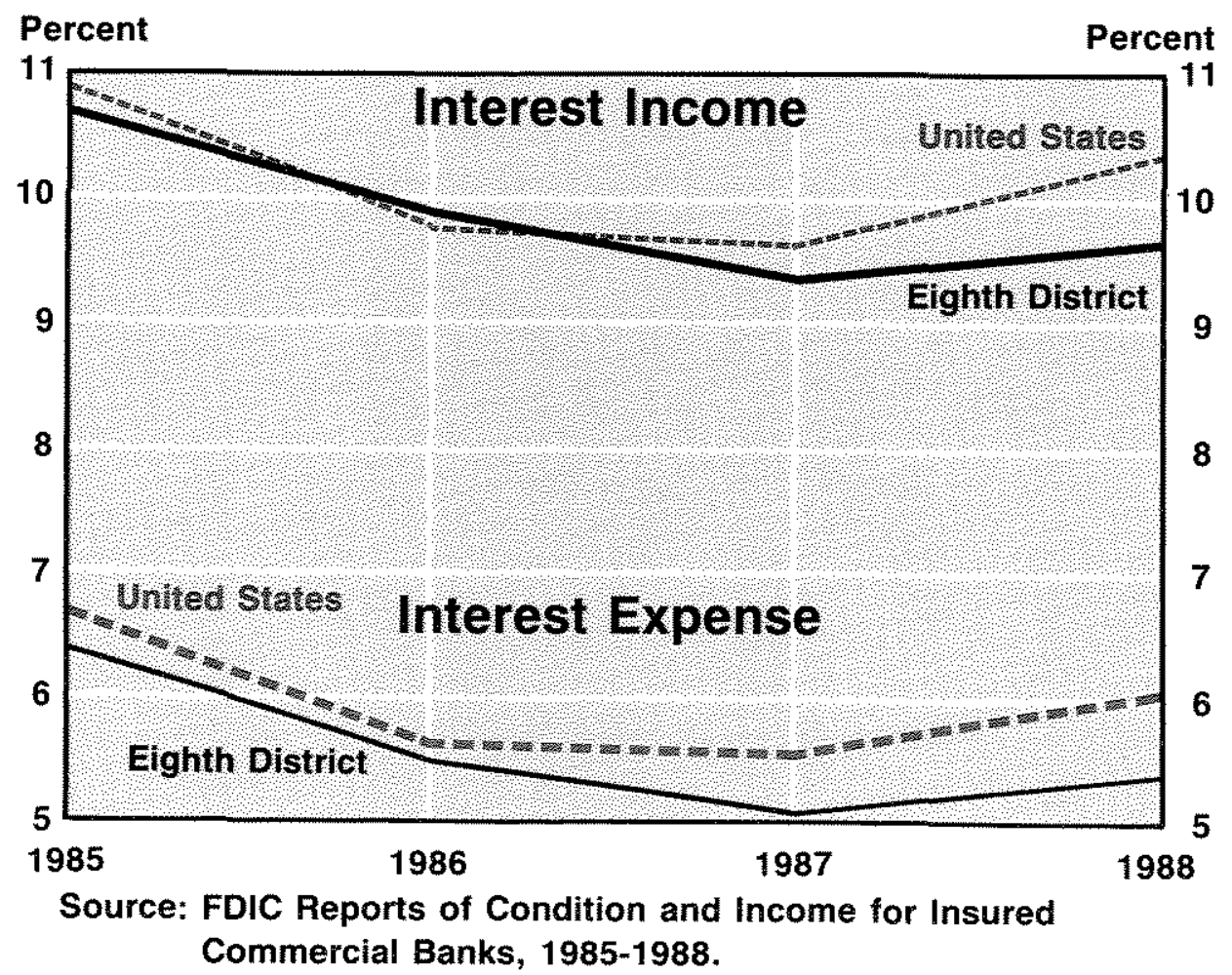

To supplement income generated from interest-earning assets, banks have attempted to generate more fee-related income. For example, service charges on deposit accounts, leasing income, trust activities income, credit card fees, mortgage servicing fees and safe deposit box rentals.

Noninterest expense includes all the expense items involved in overall bank operations, such as employee salaries and benefits as well as expenses of premises and fixed assets. Noninterest expense also covers such items as directors' fees, insurance premiums, legal fees, advertising costs and litigation charges.

For the periods presented in table 3, District banks have lagged national averages in terms of generating noninterest sources of revenue. Noninterest expense, on the other hand, has continually been lower at District banks than for banks across the nation. In 1988, noninterest income continued to average around 1. percent of average assets at District banks. Noninterest expense also remained virtually flat at about 3 percent of average assets. Noninterest expenses generally have been declining, particularly at District banks with assets between $\$ 300$ million and $\$ 1$ billion. In recent years, banks have undertaken numerous consolidation and cost-control measures to reduce fixed overhead costs. For many banks, cost reductions, including staff cuts, could have been a main contributor to profits in 1988.

\section{Loan and Lense Loss Provision}

Declining loan and lease loss provision levels helped boost earnings both in the District and the nation last year. In 1987, many large banks allocated huge sums to their loan and lease loss provision account to allow for their deteriorating foreign loan portfolio. This was a precau- 


\section{Table 3}

\section{Noninterest Income and Noninterest Expense as a Percentage of Average Assets}

\begin{tabular}{|c|c|c|c|c|c|c|c|c|}
\hline Nonnterest licome & & & & & & & & \\
\hline & pistigl & Us. & $0101 / \mathrm{ct}$ & $1 \%$ & bisingt & ns & oistrigt & Usse \\
\hline Noants & 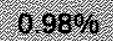 & 1,446 & $1000 \%$ & 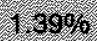 & $1.010 \%$ & 1,270 & 0.940 & $1.160 \%$ \\
\hline ( 525 willon in assets & 0.6 & 0.69 & 051 & 005 & 0.5 & 0.85 & 085 & 679 \\
\hline $125-850$ inilon & 0.6 & 076 & 053 & 0.6 & 0.52 & 0.70 & $0.5 \%$ & 0.72 \\
\hline 550.100 nilien & 0,5 & 078 & 0.53 & 014 & 0.52 & 074 & 0.53 & 0.14 \\
\hline (100 $\$ 800$ millon & 074 & 0.87 & 0.7 & 0.68 & 076 & 0.88 & 079 & 686 \\
\hline 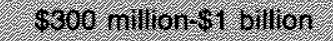 & 1.23 & 100 & 139 & 110 & 126 & 111 & 114 & 1.08 \\
\hline 1) 101011101 & 151 & 1,49 & 1.52 & 144 & 969 & 139 & 160 & 1.48 \\
\hline Morinterest Etpense & 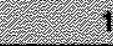 & & & & & & & \\
\hline & Distriet & (1s) & Busfict & U.s. & Distres & 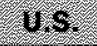 & Distifet & vs \\
\hline Marks & 29706 & 3279 & 2.5800 & $9.260 \%$ & $2.98 \%$ & 32006 & $2976 \%$ & 0.100 \\
\hline - 526 rillon In assets & 807 & 877 & 308 & 906 & 309 & 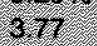 & 304 & 669 \\
\hline $9=5,550$ 11110n & 271 & 5.69 & 260 & 920 & 265 & 4. 28 & 268 & 324 \\
\hline$\$ 50 . \$ 100$ millon & 2.56 & 9. 18 & 251 & 3.19 & 259 & 8.21 & 257 & 3.18 \\
\hline \$10083600 milon & 2.76 & 323 & 2.81 & 6.26 & 2.74 & 324 & 276 & 324 \\
\hline 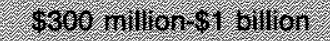 & 3.32 & 98 & 3.37 & 8.6 & 8.46 & 1,45 & 6.68 & 3. 42 \\
\hline$\$ 1, \$ 10$ billoi & 327 & 3.42 & 8.27 & 841 & 6.80 & 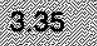 & 8.28 & 5.44 \\
\hline $5.610 \mathrm{~g} / 1 \mathrm{Hon}$ & 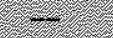 & 816 & -2 & 810 & $=0$ & 2.95 & 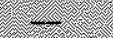 & 269 \\
\hline
\end{tabular}

SOURGE FDIC Reports of Gohdilon and hcome for Insured Fommercial Banks, 1985.1969

tionary measure to absorb expected future losses. Having taken this action in 1987, many banks saw little need to increase provision levels in 1988 .

Loan and lease loss provision totaled $\$ 450.6$ million at District banks in 1988 , down $\$ 246.6$ million from 1987 levels. As reported in table 4 , Eighth District banks decreased their provision for loan and lease losses to 0.37 percent of average assets, a sharp drop from 0.60 percent in 1987. This decrease can be traced primarily to the largest District banks. For those banks, provision for loan and lease losses fell from 0.97 percent of average assets in 1987 to 0.46 percent in 1988 .

Nationally, banks decreased their loan and lease loss provision by $\$ 20.2$ billion and, at year-end 1988, the account stood at $\$ 17.2$ billion. As a percent of average assets, loan and lease loss provision was 0.51 percent in 1988, a substantial decline from 1.24 percent in 1987 . As with the District, the largest banks were primarily responsible for the decrease as their ratio fell from 2.02 percent in 1987 to 0.42 per. cent in 1988 .

\section{ASSRT OUALTTV}

As it has for some time, asset quality continues to be a primary factor influencing the banking industry's earnings pattern. With loan losses rising over the past few years at many commercial banks, investors and regulators alike are focusing on asset quality in assessing the health of the banking industry.

Asset quality typically is measured by two indicators. The first measure, the nonperforming loan rate, indicates both the current level of problem loans as well as the potential for future loan losses. The second indicator, the ratio of net loan losses to total loans, shows the percentage of loans actually written off the bank's books.

\section{Nonperforming loans and Leases}

The level of nonperforming assets includes all loans and lease financing receivables that are 90 days or more past due, are in nonaccrual status or are restructured because of a deterioration in the financial position of the obligor. In the District, nonperforming assets decreased $\$ 246.5$ 


\begin{tabular}{|c|c|c|c|c|c|c|c|c|}
\hline & \multicolumn{2}{|c|}{1938} & \multicolumn{2}{|c|}{1987} & \multicolumn{2}{|c|}{1986} & \multicolumn{2}{|c|}{1985} \\
\hline & Distrier & U.s. & Disirict & U.S. & District & U.S. & Bistrict & U.S. \\
\hline All banks & $0.37 \%$ & 0.5106 & $0.609 \%$ & $1.24 \%$ & 6.5000 & $0.78 \%$ & $0.590 \%$ & $0.67 \%$ \\
\hline zses millon hn assets & 0.30 & 0.60 & 0.49 & 0.82 & 0.68 & 1.15 & 080 & 107 \\
\hline S25-\$50 millon & 0.32 & 0.53 & 0,43 & 0.72 & 0.67 & 0.97 & 0.76 & 0.88 \\
\hline $850-8100$ millon & 0.90 & 0.47 & 0.41 & 0.60 & 0.62 & 0.85 & 0.64 & 0.81 \\
\hline s 100-s300 millon. & 0.36 & 0.47 & 0.45 & 0.56 & 0.64 & 075 & 0.53 & 0.63 \\
\hline \$300 nillion st bilion & 0.36 & 0.59 & 0.42 & 0.70 & 0.68 & 0.85 & 0.61 & 0.63 \\
\hline Selesto billion & 0.46 & 0.69 & 0.97 & 0.90 & 0,46 & 0.67 & 0.48 & 0.57 \\
\hline - 510 billion & $=$ & 0.42 & & 202 & & 0.80 & 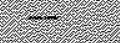 & 0.70 \\
\hline
\end{tabular}

SOUACE: FUIC Reports of Condilin and Income for Insured Comnercial Banks, 1985-1986:

\section{Table 5}

\section{Nonpertorming Loans and Leases as a Percentage of Total Loans}

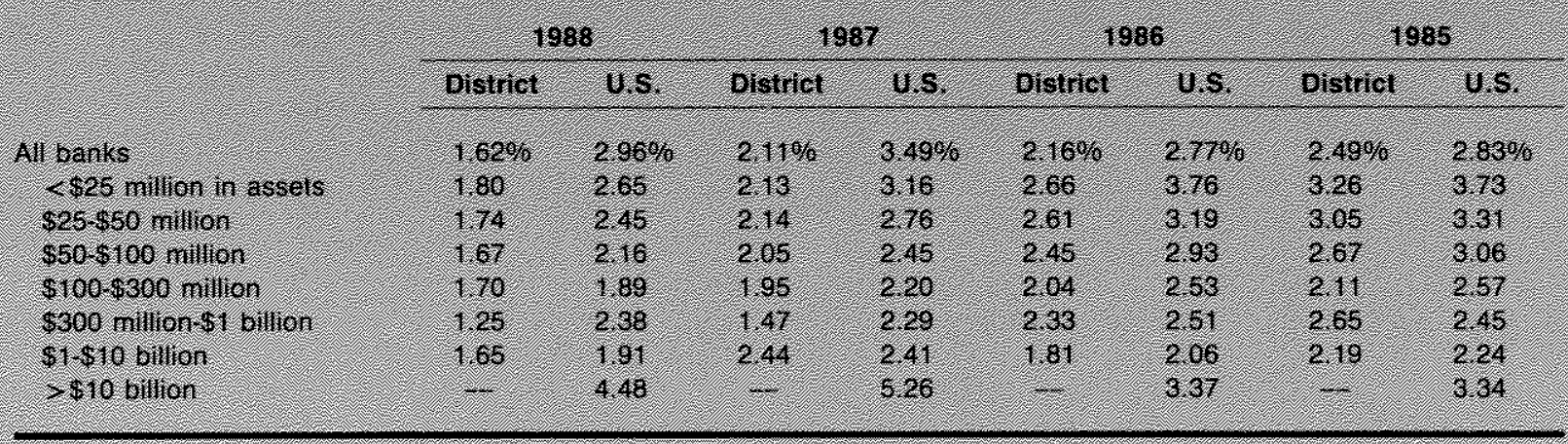

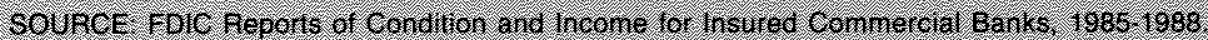

million from 1987 to 1988 . As reported in table 5, Eighth District banks' nonperforming loans and leases as a share of total loans fell from 2.11 percent in 1987 to 1.62 percent in 1988 . Banks across the nation experienced a similar decline as the nonperforming loan rate dropped from 3.49 percent to 2.96 percent.

Across all asset-size categories, District banks reported a decrease in nonperforming loans and leases in 1988. District banks with assets less than $\$ 25$ million saw nonperforming loans and leases fall from 2.13 percent of total loans in 1987 to 1.80 percent in 1988 . The largest District banks saw their nonperforming loan rate drop from 2.44 percent to 1.65 percent during the same one-year period. Nationally, this pattern also held true as most asset-size cat- egories reported a decline in the nonperforming loan rate. The only exception was at banks with assets between $\$ 300$ million and $\$ 1$ billion where nonperforming loans and leases rose to 2.38 percent of total loans, up from 2.29 percent in 1987 .

Figure 2 shows the distribution of nonperfor. ming loans by loan type for Eighth District banks. At year-end 1988, nonperforming agricultural loans as a percent of total nomperforming loans was 5.45 percent, down from 6.84 percent in 1987 . The percentage of nonperforming commercial loans fell from 45.91 percent of the total to 41.14 percent. Consumer nonperforming loans, which accounted for 6.88 percent of the total in 1987 , rose to $8.61 \mathrm{per}$ cent in 1988. Nonperforming real estate loans had a fairly substantial increase in 1988, rising from 35.81 percent in 1987 to 42.45 percent. 


\section{Figure 2 \\ District Distribution of Nonperforming Loans by Loan Type}

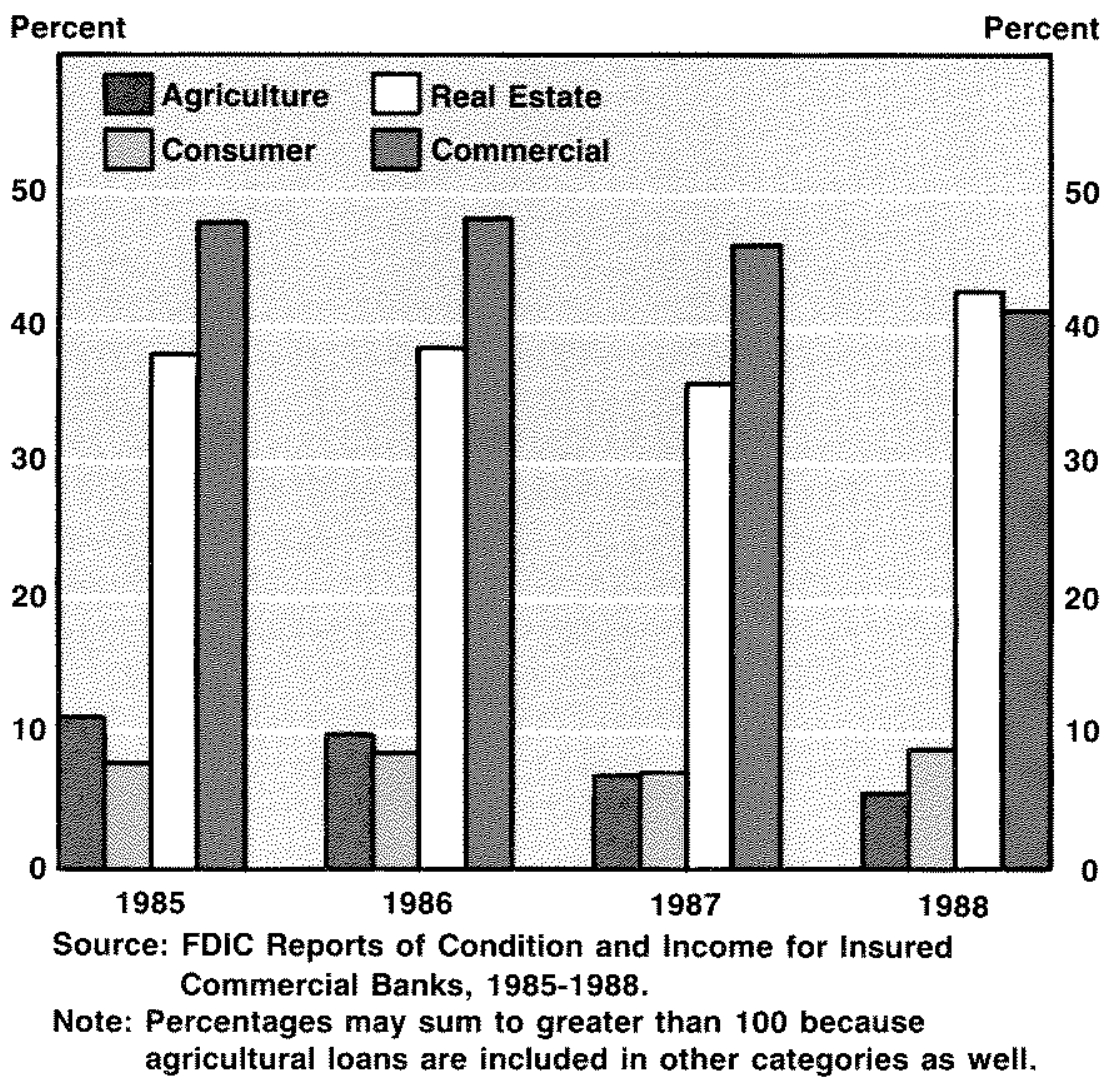

\section{Loan and Lease Losses}

The most direct measure of a bank's loan problems is the percentage of loans and leases charged-off during the year. Net loan and lease losses (adjusted for recoveries) amounted to $\$ 510.8$ million at District banks in 1988 , an in. crease of $\$ 46.7$ million from 1987. Nationally, banks charged-off $\$ 17.6$ billion in $1988, \$ 1.5$ billion more than in 1987. As table 6 shows, the average charge off rate at banks in the Eighth District rose slightly in 1988 , from 0.70 percent of total loans in 1987 to 0.72 percent. Nationally, the average charge-off rate rose from 0.89 percent of total loans in 1987 to 0.93 percent in 1988. Across virtually every asset-size category, charge off rates at District banks were lower than at their national counterparts. The only exception was at the largest District banks where net loan losses and leases to total loans jumped sharply in 1988 , from 0.68 percent in 1987 to 1.18 percent.

Table 7 shows the distribution of loan losses by type of loan. For both the nation and the District, commercial loan losses contributed the greatest percentage to overall loan loss. The percent of District commercial loan charge-offs fell in 1988, from more than 50 percent of total loan losses in 1987 to approximately 44 percent. Farm-related charge-offs declined further in 1988 and now account for slightly more than 2 percent of total District loan losses. The percentage of District consumer loan charge-offs also declined in 1988, falling from 23.24 percent in 1987 to 17.88 percent of total loan losses. Only one category, loans held in foreign offices, increased in 1988. Loan losses for this category increased to 17.51 percent of overall loan loss, up substantially from 1.79 percent in 1987 . 
Table 6

Net Loan and Lease Losses as a Percentage of Total Loans

\begin{tabular}{|c|c|c|c|c|c|c|c|c|}
\hline & \multicolumn{2}{|c|}{1988} & \multicolumn{2}{|c|}{1097} & \multicolumn{2}{|c|}{1086} & \multicolumn{2}{|c|}{1085} \\
\hline & vistrat & U.S. & Distiver & is. & solfcu & 18 & oprotict & 1. \\
\hline Ar bonks & $0.72 \%$ & $0.93 \%$ & 0.7000 & 0.6906 & 0.8506 & $0.946 \%$ & $0.89 \%$ & $0.81 \%$ \\
\hline (48525 nullor in assets & 0.60 & 1.18 & 0.95 & (2) 36 & 1,32 & 2.02 & 1.59 & 171 \\
\hline 825850 ninor & 0.5 & 0.80 & 070 & (1) 17 & 1.16 & 161 & 188 & 188 \\
\hline $950-5100$ N11IJon & 046 & 67 & 0.70 & 6.96 & 1.07 & $(1,36$ & 1.09 & 1.22 \\
\hline $100 \% 3300$ nillon & 0.50 & 066 & 0.67 & 0.78 & 0.90 & 108 & 0.72 & 0.84 \\
\hline 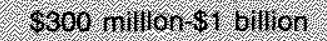 & 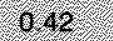 & 079 & 071 & 0.89 & 0.92 & 099 & 0.76 & 074 \\
\hline 81.810 billon & t. & 0.94 & 0.68 & 0.86 & 0.57 & 0.73 & 0.59 & 064 \\
\hline$=610,0110 \mathrm{n}$ & 8 & 106 & (2) & 0.88 & r. & 0.89 & 2 & 0.77 \\
\hline
\end{tabular}

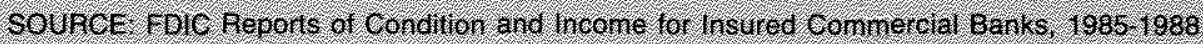

Table 7

\section{Distribution of Loan Losses}

\begin{tabular}{|c|c|c|c|c|}
\hline & 1988 & 1967 & 1086 & 1965 \\
\hline \multicolumn{5}{|l|}{ Eistriet } \\
\hline Aurculivie & $2.24 \%$ & $826 \%$ & $1610 \%$ & ( $94.4 \%$ \\
\hline Oominergre & 44,42 & 51.51 & 62.20 & 66.60 \\
\hline Consuner & 17.66 & 2324 & 18.56 & 150 \\
\hline Real estare & 16.63 & 19.10 & 705 & $18 \% 6$ \\
\hline Forabnt & 17.51 & 170 & 0.16 & 0.87 \\
\hline \multicolumn{5}{|l|}{ Hnited states } \\
\hline Agreulure & $017 \%$ & $3.350 \%$ & 7660 & $10.35 \%$ \\
\hline Cominerela & 6647 & 45.18 & 5567 & 6007 \\
\hline Comsurier & 26.89 & 2866 & 26.69 & 20,16 \\
\hline Mova estave & 13.42 & 1520 & 1,76 & 8.59 \\
\hline porcigh & 1070 & 6.60 & 1,10 & 255 \\
\hline
\end{tabular}

Iloans neld in loregn oflices, Edge and Agreenent Subsidlaties und htenatonal Banking Faciltes (IBFs)

Nol E Percentages nay surn 10 greater han 100

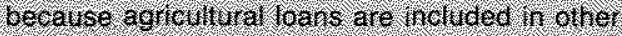
categones as well

SOURCE f fle reports or Condion ard heome for in sured Comnerchal Banks, $1985-1998$

\section{CAPITAL ADEOUACY}

Bank regulators have a strong interest in en suring that banks maintain adequate financial capital. Bank capital is intended to absorb losses, cushion against risk, provide for asset expansion and protect uninsured depositors. Given its importance, the regulatory agencies have set minimum standards of 5.5 percent primary capital to assets and 6 percent total capital to assets. ${ }^{3}$ These standards have been revised recently and, on December 16, 1988, the Federal Reserve Board approved new risk-based capital guidelines intended to encourage banks to make safer investments. ${ }^{9}$

The improved performance of District banks had a favorable effect on their capital levels. As table 8 indicates, improvement in bank primary capital ratios is apparent throughout most assetsize ranges. Average primary capital ratios for banks both in the District and nationwide are well above the current minimum standards established by the regulatory agencies. Nation ally, an average primary capital ratio of 7.92

bank's secondary capital is added to its primary capital to obtain the total capital level for regulatory purposes.

9The guidelines establish a systematic framework whereby regulatory capital requirements are more sensitive to dif ferences in risk profiles among banking organizations. In addition, off-balance sheet activity is evaluated for risk exposure. The guidelines provide for a phase-in period through the end of 1992 at which time the standards become fully effective. Starting December 31, 1990, the level of capital that banks are required to hold will increase to 7.25 percent of qualifying total capital to weighted risk assets and, finally, to 8 percent in 1992. capital and includes subordinated notes and debentures, limitedifife preferred stock and that portion of mandatory convertible securities not included in primary capital. Each 


\section{Table 8}

\section{Primary Capital Ratios}

\begin{tabular}{|c|c|c|c|c|c|c|c|c|}
\hline & \multicolumn{2}{|c|}{1080} & \multicolumn{2}{|c|}{1987} & \multicolumn{2}{|c|}{1986} & \multicolumn{2}{|c|}{1985} \\
\hline & oldingt & 0.5 & pistict & Us & Mistiret & 0.5 & Bistrol & 0.5 \\
\hline II $6 \mathrm{ank}$ & 6.796 & 7.920 & 6780 & 7804 & 6.700 & $7-76 \%$ & $8.380 \%$ & 7.44 \\
\hline ( s. 5 h nillon in assets & 10.44 & 1002 & 10.14 & 10.59 & 907 & 10.36 & 9.86 & 10.56 \\
\hline 925.550 nillon & 9.70 & 9.68 & 0.53 & 969 & 927 & 9.30 & 921 & 9.36 \\
\hline 150.5100 nn111an & 9.49 & 928 & 97 & 90 . & 9.00 & 809 & 0.91 & 670 \\
\hline$\$ 10098600$ millon & 6.66 & 8.62 & 8,1 & d. 59 & 8.50 & 6.26 & 8.97 & 617 \\
\hline$\$ 300$ nillonst bIIon & 855 & 190 & 8. 50 & 787 & 800 & 7.91 & 6.35 & 6.67 \\
\hline S 4510 billon & 766 & 7,45 & 789 & 750 & 752 & 7.31 & 78 & 78 \\
\hline 5810 billan & rej & 758 & 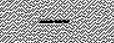 & 726 & 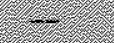 & 687 & 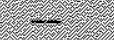 & 6.61 \\
\hline
\end{tabular}

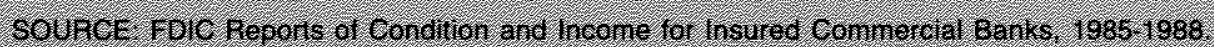

percent was reported, up slightly from 1987 . While District aggregate primary capital ratios remained the same in 1988 , some asset-size groups showed notable improvement. In particular, the smallest District banks reported an average primary capital ratio of 10.44 percent in 1988, up from 10.14 percent in 1987 . In contrast, the largest District banks reported a decline in their average primary capital ratio, falling from 7.89 percent in 1987 to 7.66 percent in 1988.

As of December 1988, six banks or 0.5 percent of all District banks fell short of the minimum regulatory primary capital standards. This number was down from 15 banks in 1987. Nationally, 465 banks had deficient primary capital ratios at year-end 1988, compared with 474 in 1987.

\section{CONGESION}

1988 marked a year of recovery from the overall poor earnings reported by banks across the nation in 1987. Bank performance in the Eighth Federal Reserve District improved in
1988, propelled by lower loan loss provisions. Aggregate bank profit ratios improved as many of the District's largest banks began to rebound from the negative earnings associated with increased loan loss provisions tied to foreign loans. Profits recouped across virtually every as. set size category of Eighth District commercial banks. The smaller District banks employed higher earnings as both loan losses and loan loss provisions levels declined.

As with most of the banking industry, better asset quality helped to improve earnings at District banks last year. Finally, a majority of Eighth District banks improved their primary capital ratios in 1988 and are positioned well above the minimum standards set by bank regulators.

The banking industry in the Eighth District has returned to profitability, and, barring any shocks, should continue to improve in the com. ing quarters. With a continued positive economic environment, loan problems that have plagued District banks should abate and as the level of nonperforming loans declines, future loan problems should be less severe. 